\title{
DETERMINATION OF STUDENT DECISION FACTORS IN CHOOSING STUDY PROGRAMS IN THE FACULTY OF PUBLIC HEALTH AT ANDALAS UNIVERSITY, INDONESIA
}

\author{
Armeilia Dessy* \\ Business School, Bogor Agricultural Institute, Indonesia \\ Simanjuntak Megawati \\ Department of Family and Consumer Sciences, Faculty of Human Ecology, Bogor \\ Agricultural Institute, Indonesia \\ Amanah Siti \\ Department of Science in Communication and Community Development, Faculty of Human \\ Ecology, Bogor Agricultural Institute, Indonesia \\ *E-mail: dessyarmeilia@gmail.com
}

\begin{abstract}
Selection of study programs for students requires several considerations before making a decision in determining the place of study. This study aims to identify the student's decision to choose a study program at the Faculty of Public Health Unand, analyze the factors that influence the student's decision to choose a study program at the Faculty of Public Health Andalas University, and formulate managerial implications related to strategies to increase the number of applicants and those who apply to Unand FKM. This study was conducted on students of Public Health and Nutrition Sciences in 2017 and 2018 who actively carry out lectures with a total sample of 391 . The variables of this study are product, people, process, promotion, physical evidence, campus image and employment. The data collection method uses a questionnaire with a Likert scale, analyzed using SEM. The results showed that the factors of product, process and promotion had a significant direct influence on the decision of students to choose a study program at the Faculty of Public Health Unand.
\end{abstract}

\section{KEY WORDS}

Partial least square, campus image, employment, marketing mix, decision to choose, study program.

Fulfilling education needs in Indonesia is one of the nation's goals set out in Law Number 12 of 2012, concerning higher education. Higher education as part of the national education system has a strategic role in educating the nation's life and advancing science and technology by paying attention to and applying the values of humanities and the empowerment of a sustainable nation of Indonesia. The selection of study programs for students requires several considerations before making a decision in determining the place of study later. Engel et al. (1995) states that consumer decisions in choosing products / services are influenced by three things: 1. Internal environment / individual consists of consumer resources (time, money, and attention), motivation and involvement, knowledge, attitude, personality, lifestyle and demography; 2. The external environment consists of cultural factors, social class, personal, family and situation influences; and 3. Psychology consists of information processing, learning, attitude and behavior changes.

There are six important factors when choosing a study program, namely factors related to family / parents, peers, school of origin, individual personality, campus image and employment prospects (Saputro 2017). Opinions from the family and individual interests are the main factors in choosing a place to study (Yamamoto 2006). Product, price, promotion, place, people, process and physical evidence have an influence on the decisions of students choosing the MIPA UNMUL Faculty of Computer Science majors (Merni 2011). Institutional 
images and future work have a significant influence on students choosing to study at the University of Taiwan (Yao-Chuan Tsai (2017). A good image of an organization is an asset that has an impact on consumer perceptions can be seen from the organization's communication and operations in various ways, this has an influence on the decision to choose an accounting department (Risnawati 2012), followed by interest factors, shared decision factors, and the availability of employment opportunities for accounting graduates.

The development of the world of education in Indonesia, there are many public universities and private universities that open public health faculties, including STIKES which also establishes public health science and nutrition science study programs that make competition even higher. The faculty and study program must strive to improve the quality and provide the best education for recipients of services, namely students. Students applying for and being accepted at the Unand Faculty of Public Health experienced quite volatile changes from 2016 to 2018. The ratio of the number of applicants and the number received in 2016 was: $1: 30.55$, in 2017 amounting to $1: 24.21$ and in 2018 is $1: 29.17$. This means that student tightness / competition chooses FKM is quite high. This must be improved to get quality students, to produce quality and useful graduates in the labor market. Based on the above problems this study takes the title of the determinants of student decisions in choosing a study program at the Faculty of Public Health Unand.

This study aims to identify the student's decision to choose a study program at the Faculty of Public Health Unand, analyze the factors that influence student decisions to choose a study program at the Faculty of Public Health Unand, and formulate recommendations for strategies to increase the number of applicants and those who apply to Unand FKM.

\section{LITERATURE REVIEW}

According to Kotler (2009) and Engel et al. (1995) decision making on purchasing products / services is influenced by several factors, namely:

1. Cultural Factors. Culture is a value, thought and symbol that influences a person's behavior, attitudes, beliefs and habits;

2. Social Factors. Consumer behavior is influenced by social factors such as reference groups, families and the role and status of consumers;

3. Personal Factors. Personal factors are individual habits that are influenced by the closest environment in making choices, and then expressed in an action (Purimahua 2005);

4. Psychological factors. Psychological factors are encouragement from someone who influences the selection of something based on the flexibility of the product used, greater desire and ease of use of the product compared to others.

Marshall and Jhonston (2010) state that the marketing of traditional marketing mix concepts consists of $7 \mathrm{P}$, namely:

- Product. Product services are all things that can be offered by producers to be considered, requested, sought, bought, used or consumed by the market as meeting the needs or desires of the relevant market;

- Price. Price is the amount of money customers pay for a particular product;

- Place. Location is a place where services are provided. Location determination includes consideration of how to deliver services to customers where services must be placed;

- Promotion. Promotion is an activity carried out by a company or organization to communicate and promote its products to the target market;

- People. People are an important element in producing and delivering services;

- Physical evidence. Physical Evidence is the physical environment in which services are delivered, and there is an interaction between service providers and consumers;

- Process. Process is a procedure, mechanism, and series of service delivery activities. Service marketing is carried out because services have different characteristics from 
products, namely: intangibility, inseparability, variability and perishability. Service marketing is different from product marketing.

The image of higher education as defined by Kotler and Fox (1995) are images, impressions and beliefs that a person has towards an object and object in the form of an organization. The good image given by an organization has become an asset because the image itself is the impact of consumer perceptions that come from communication and operations of the organization in various fields.

The determinants of students in choosing study programs are factor product, people, process, promotion, physical evidence of campus image and employment. Following are the results of previous research studies based on these factors:

1. Product Factors. Choosing a study program for students requires some consideration before making a decision. According to Rodic et al. (2016) the product has a positive influence on students' decisions to choose faculties at University Novi Sad, Serbia. This study uses the interview method with a questionnaire. The sample is students in six faculties at this university with 783 students as respondents. This is reinforced by Handayani (2017) who conducted research on marketing mix analysis of students' decision to choose study programs. The results of his research show that the product has a significant and positive effect on the decision to choose students. This study uses the interview method with a questionnaire. The sample is a student at the Faculty of Economics, University of Bojonegoro with a number of respondents of 100 students. The main objective of students choosing study programs is to obtain products / knowledge that are in accordance with their needs and desires, so that students can be said to enter the product in the form of knowledge they need (Merni 2011).

2. People Factor. The application of better marketing mix elements, especially people, has a significant influence on students' decisions to choose study programs at Covenant University Nigeria (Ogunnaike 2014). The sample is a student of the Business Management Department with 226 students. People's variables in the research conducted by Merni (2011) state that lecturers and administrative staff play an important role in the decision of students to choose majors in higher education. The sample is a student of the Department of Computer Science, Faculty of Mipa Unmul with 195 students. Raharjo et al. (2015) and Fosu at al (2017) identify that people have a positive influence on the decision of students to choose a place to study. The decision to choose a place to study becomes an important thing because it involves the future for the students themselves.

3. Process Factors. Muhyidin (2014) states that process variables have a significant influence on the decision of students to choose a place of study. This study uses descriptive quantitative methods and questionnaires. The sample is new students in 15 PTS in West Java who actively study in the odd semester of the 2013/2014 academic year with a total of 341 students. The process in education services greatly determines the quality of a college graduate. Similar results were found in the Suryani et al. (2013) that the process variable significantly influences the decision of students to choose the place of birth. Ogunnaike (2014), Kurniawati (2013), Handayani (2017) and Raharjo et al. (2016) identifying process variables have a significant influence on students' decision to choose a place of study.

4. Promotion factor. Promotion factor is a way that makes it easier to convey information related to education services. Osman (2013) found that promotion had a positive and significant influence on students' decision to choose study programs at Malaysian Universities. The sample is all middle school students with 373 students. Samat et al. (2017) in his research stated that promotion variables have a significant influence on student decisions in choosing a place to study. The sample is students who study in five universities in Palembang City with a total of 110 students. Ade (2016) states that promotion variables in the marketing mix have a significant influence on the decision of students to choose majors in higher education.

5. Physical evidence factor. Suryani et al. (2013) examined the factors that influence students' decisions in choosing departments in the faculty. His research found that evidence physical variables influence the decision of students to choose a place to study. The sample is students of the Faculty of Economics, Islamic University of North Sumatra, Al Munawaroh, 
2009 to 2012 with a sample of 460 students. Ogunnaike (2014), Merni (2011), Handayani (2017), Raharjo et al. (2016) and Ade (2016) found the same results of research that physical evidence had a significant effect on students' decisions to study.

6. Campus Image Factors. Campus image has a big role in influencing decision making for students. Yao-Chuan Tsai (2017) states that institutional images have a significant influence on students choosing to study at Taiwan University. This study uses the method of direct interview and questionnaire. The sample is international students studying in Taiwan with 210 students as respondents. The results of this study are reinforced by Fakhri at al (2017) and Saputro (2017), who concluded that there was a significant effect of campus image on the decision of students to choose a place to study. This indicates that even though students do not know the product or brand of a campus, students can choose through the image of the campus.

7. Factors of Employment. Employment is one of the main concerns for students in determining the place of study. The results obtained from Risnawati's research (2012) is that there is a significant influence on the employment prospects of the decision to choose students. The sample is a student of accounting major in 2011 STIE Perbanas Surabaya with 435 students. Yao-Chuan Tsai (2017) future work has a significant influence on students choosing to study at Taiwan University. Likewise, the results of research conducted by Saputro (2007) state that employment has a positive effect on student decisions in choosing a place to study. The sample is a student of the 2015/2016 and 2016/2017 Academic Year Program with a total sample of all students in the academic year.

\section{RESEARCH HYPOTHESIS}

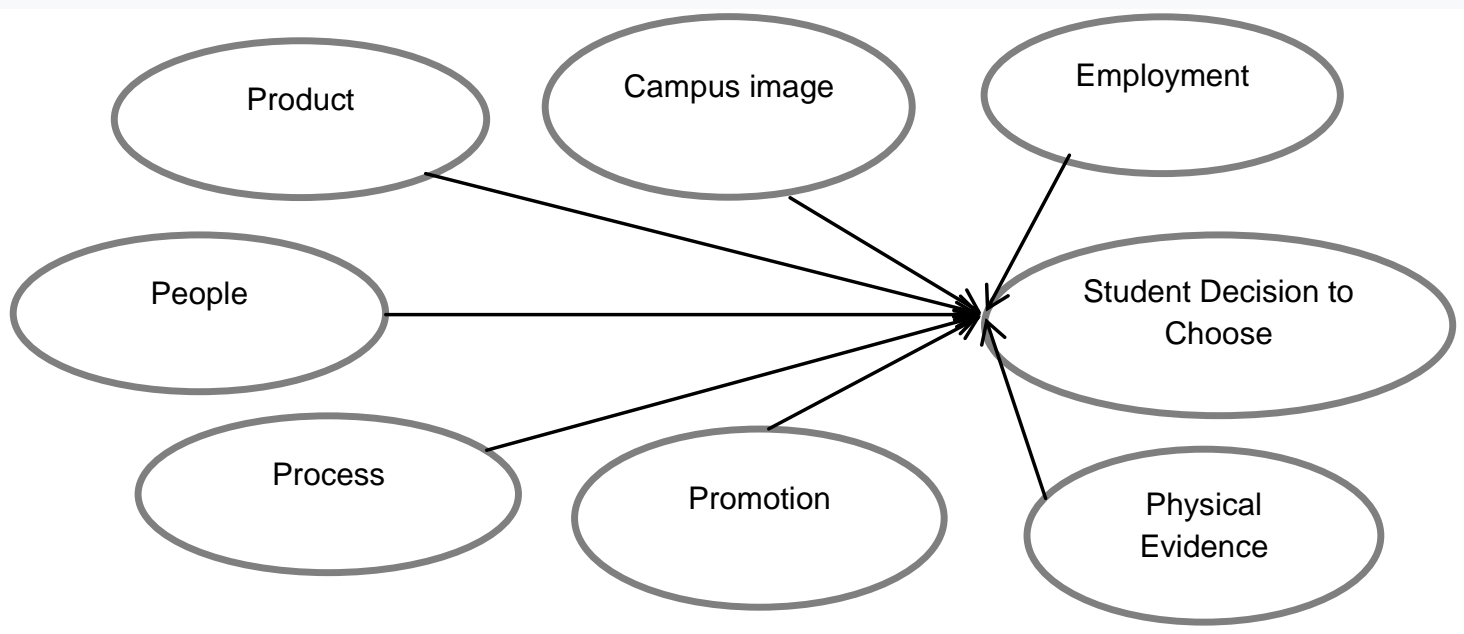

Figure 1 - Framework for thinking

This study consists of 7 hypotheses, namely $\mathrm{H} 1$ : Product has a significant effect on the decision to choose a study program, H2: People has a significant effect on the decision to choose a study program, H3: Process has a significant effect on the decision to choose a study program, H5: Physical evidence has a significant effect on the decision to choose a study program, H6: Campus image has a significant effect on the decision to choose a study program, and H7: Employment has a significant effect on the decision to choose a study program.

\section{METHODS OF RESEARCH}

The study was conducted at the Faculty of Public Health of Andalas University, with student research subjects in 2017 and 2018 who actively conducted lectures. Research data collection was conducted from February to March 2019. The sources and types of data used were primary data. Primary data used by researchers include product, people, process, 
promotion, physical evidence, campus image and employment and student decisions to choose study programs. As for the sample of all S1 students who are actively studying at the Unand Faculty of Public Health in 2017 and 2018, there are 391 active students. The sampling technique is carried out by census or saturated samples. Saturated census or sample is a sampling technique if all members of the population are used as a sample (Sugiyono 2015). Data and information were collected by distributing closed questionnaires to respondents, filling out questionnaires conducted self-administered by being guided directly by researchers. This study used descriptive analysis with SPSS24 and SEM-PLS analysis.

\section{RESULTS AND DISCUSSION}

Decision Making Process. The results showed that the highest consideration in choosing the Unand Faculty of Public Health was the $60 \%$ offered and $13 \%$ reputation offered. With this situation, FKM Unand must improve its existence, especially related to the field of science offered and reputation. Rudhumbu (2017) also found that study programs and locations were the highest factors in choosing universities in Botswana.

The most widely used source of information is through mass media (websites, brochures, newspapers) with a percentage of $28 \%$, a nuclear family of $19 \%$ and teachers (teachers in schools, at tutoring places) of $19 \%$. This shows that respondents are easier to get information about FKM Unand, especially through mass media, nuclear families and teachers. Osman (2013) in his research also found that students choosing institutions were mainly promoted through radio and television in Malaysia.

The giver of influence in choosing the Unand Faculty of Public Health showed the highest results were obtained from the students' own interest of $61 \%$, while the influence of the family (parents, siblings) was $18 \%$ and teachers (teachers in the school, teachers on the guidance place) were 7\%. Family opinion and student interests are the most important factors that influence student choice (Yamamoto 2006).

Description of Variable Indicators. The results showed that the availability of expertise and skills in accordance with employment became an attraction for respondents in choosing FKM Unand study program, which amounted to $60.4 \%$, while for science that was in accordance with needs / desires $57.3 \%$ and knowledge that made it easy to get a job after graduating $52.7 \%$. More can be seen in Table 1 . This illustrates that respondents really need expertise, skills and knowledge in accordance with their needs and desires to compete in the world of work. Merni (2011) also suggested that students enter the computer science department of F.MIPA UNMUL to obtain products / knowledge according to their needs and desires.

Respondents want competent lecturers in the field of science to be taught at $70.8 \%$ and administrative staff in providing good services to students by $33.2 \%$. More can be seen in Table 1. The results of this Unand FKM need to improve the knowledge and skills of lecturers and administrative staff in order to produce qualified and competent graduates. Internal environmental factors including people are important for students in choosing majors at FEB Undiksha (Ayu 2014). Lecturers are an important factor in changing students' perceptions of an institution (Osman 2013).

In the process variables, more than $50 \%$ of students choose student activity indicators to increase the soffskill, provide clear curriculum / syllabus / lecture methods and produce graduates on time, while indicators produce competent graduates with a short work waiting period of under $50 \%$. More can be seen in Table 1 . This shows tense when graduates get a job long enough, because the cooperation carried out by FKM with companies and hospitals has not been well established, as is the alumni network that has not been well organized. Muhyidin (2014) also argues that the better the process will affect the increasing decision of students to choose certain universities.

Promotional activities through dissemination to schools are the main choices of respondents, amounting to $39.4 \%$, promotion via the internet / website by $30.9 \%$ and promotion through brochures / leaflets of $23.8 \%$. More can be seen in Table 1 . This shows 
that promotions carried out through socialization to schools will quickly arrive or be accepted by prospective students. Likewise through the internet / website because the age range of 17-19 is very active in using the internet to obtain the information they need. Promoting school visits led by alumni from the school will be the main attraction for prospective students (Ivy 2008).

Indicators have a very complete media (infocus / sound system) teaching and learning being the highest indicator chosen by respondents at $60.3 \%$, while indicators have very good IT facilities, have complete books in the library, have very good laboratory facilities complete and have a very adequate building below $60.3 \%$. More can be seen in Table 1 . This shows the supporting facilities for teaching and learning activities in Unand FKM are the availability of media (infocus and sound systems) and internet networks. For other facilities University facilities are used together. The completeness of the media and teaching and learning facilities in PTS is a benchmark for students in making a decision (Muhyidin 2014).

Having an accredited BAN-PT / LAM-PTKES status is the most important thing for respondents to choose a study program of $80.3 \%$. For indicators of good quality / quality of education in higher education, having a proud academic achievement in higher education and an IKM / Nutrition study program is the favorite choice to be the next thing chosen by respondents. More can be seen in Table 1. This shows the accredited status of a campus is very necessary to get jobs for the respondents later. Risnawati (2012) also noted that the accredited status of study programs was the main thing for students at STIE Perbanas Surabaya.

Table 1 - Percentage of student assessment based on product indicators, people, process, promotion, physical evidence, campus image, and employment on student decisions to choose study programs

\begin{tabular}{|c|c|c|c|c|}
\hline No & Indicator & TS & $\mathrm{N}$ & $\mathrm{S}$ \\
\hline & Indicator Product & & & \\
\hline 1 & Having knowledge in accordance with needs / desires & 6,4 & 36,3 & 57,3 \\
\hline 2 & Expertise and skills in accordance with existing employment & 2,8 & 36,8 & 60,4 \\
\hline 3 & $\begin{array}{l}\text { Providing knowledge that makes it easy to get a job after graduation } \\
\text { Indicator People }\end{array}$ & 4,6 & 42,7 & 52,7 \\
\hline 4 & Have competent lecturers. & 4,4 & 24,8 & 70,8 \\
\hline 5 & $\begin{array}{l}\text { Have administrative staff providing good service. } \\
\text { Indicator Process }\end{array}$ & 27,2 & 39,6 & 33,2 \\
\hline 6 & Having student activities increases skill & 2,0 & 22,3 & 75,7 \\
\hline 7 & Produce graduates on time & 3,6 & 39,4 & 57,0 \\
\hline 8 & Providing curriculum / syllabus / lecture methods & 10,0 & 28,1 & 61,9 \\
\hline 9 & $\begin{array}{l}\text { Produce competent graduates } \\
\text { Indicator Promotion }\end{array}$ & 7,7 & 56,3 & 36,0 \\
\hline 10 & Actively carry out promotions through brochures / leaflets & 22,7 & 53,5 & 23,8 \\
\hline 11 & Online promotion through internet / website & 16,6 & 52,4 & 30,9 \\
\hline 12 & $\begin{array}{l}\text { Dissemination to schools } \\
\text { Indicator Physical evidence }\end{array}$ & 13,8 & 46,8 & 39,4 \\
\hline 13 & Laboratory facilities & 33,3 & 41,7 & 25,0 \\
\hline 14 & Have books in the library & 18,7 & 43,2 & 38,1 \\
\hline 15 & Has a building (lecture room, practice room and prayer room) & 44,5 & 31,2 & 24,3 \\
\hline 16 & Has media (In focus / sound system) & 7,9 & 31,7 & 60,3 \\
\hline 17 & $\begin{array}{l}\text { It has very good IT (internet) facilities } \\
\text { Indicator Campus Image }\end{array}$ & 14,9 & 39,6 & 45,5 \\
\hline 18 & Have academic achievements (research and community service) & 3,9 & 41,4 & 54,7 \\
\hline 19 & Have good quality / quality of education in college. & 2,0 & 32,2 & 65,7 \\
\hline 20 & The Unand IKM / Nutrition study program is a favorite choice & 10,0 & 46,5 & 43,4 \\
\hline 21 & $\begin{array}{l}\text { Has an accredited BAN-PT / LAM-KES status } \\
\text { Indicator Employment }\end{array}$ & 1,6 & 18,2 & 80,3 \\
\hline 22 & Alumni have the opportunity to work in a company / hospital & 3,9 & 38,9 & 57,3 \\
\hline 23 & Graduates get jobs in accordance with the field of specialization & 4,9 & 55,5 & 39,6 \\
\hline 24 & $\begin{array}{l}\text { Graduates easily get jobs } \\
\text { Indicator Decision to Choose a Study Program }\end{array}$ & 6,9 & 56,0 & 37,0 \\
\hline 25 & In accordance with the field of specialization & 10,3 & 29,7 & 60,1 \\
\hline 26 & The ease of getting a job & 9,5 & 46,8 & 43,7 \\
\hline 27 & Campus reputation & 25,0 & 39,6 & 35,4 \\
\hline 28 & Invite friends / relatives / acquaintances & 65,5 & 17,4 & 17,1 \\
\hline
\end{tabular}

Description: $T S=$ disagree; $N=$ neutral; $S=$ agree. 
Alumni indicators have the highest chance to work in companies and hospitals having the highest score of $57 \%$, compared to the other three indicators, namely indicators of getting jobs that are in accordance with the field of specialization and easy to find work both in hotels / offices / schools / consultants. More can be seen in Table 1. This shows that the employment opportunities obtained by graduates are not necessarily in accordance with the knowledge they have because currently the market share not only sees the knowledge they have mastered but also the skills they have. Job opportunities are important for students in Taiwan in choosing a place to study (Yao-Chuan Tsai 2017).

Decision to Choose a Study Program. In this case, the highest choice of respondents choosing study programs is because the desired specialization is $60.1 \%$. Furthermore, the ease of getting a job, campus reputation and invitation from friends / relatives / acquaintances. More can be seen in Table 1. This explains that the respondents chose the study program because the field of specialization was desired. The field of knowledge desired or offered is an attraction for Bogor City Senior High Schools to choose IPB (Haryanti 2016, Solikhah 2016).

Analysis of Measurement Model Compatibility Test. Based on the convergent validity test, which is the correlation value between indicators and latent variables, the loading factor and AVE values of each indicator from a latent variable are more than 0.5 , but there are two indicators with a loading factor of less than 0.5 , the X5.5 indicator on the physical evidence variable and indicator Y4 on the decision decision variable, the indicator must be discarded and re-analyzed. The AVE analysis results obtained AVE values from the process variable indicator, X3.1, less than 0.5 , this indicator must be discarded and re-analyzed. The results of confirmatory analysis after removing invalid indicators can be seen in Figure 2.

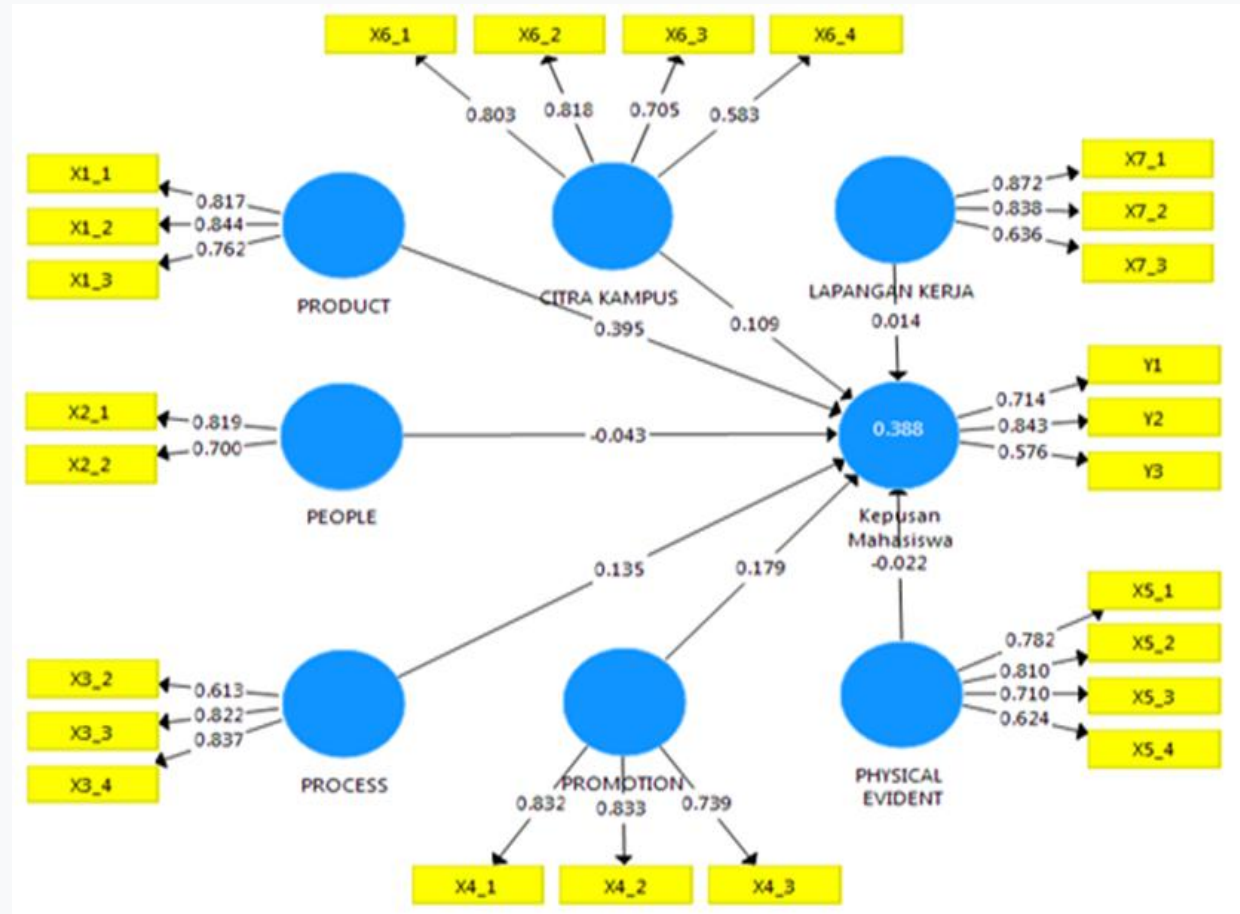

Figure 2 - SEM Results

For discriminant validity test, how far the difference in the value of the validity of a variable when compared with other variables, by comparing the value of the square root AVE and the value of correlation between verbs. Obtained AVE square root values of all variables and indicators greater than 0.7 and comparison of AVE root values greater than the correlation value between other variables. Likewise the cross loading value between variables with indicators is greater than the correlation value of other latent variables with the indicator variable. It can be interpreted that all latent variables in this study have good discriminant validity. 
Composite reliability test to measure the consistency and accuracy of internal measuring instruments that have a standard value above 0.7 . The reliability values of each latent variable, namely product, people, process, promotion, physical evedent, campus image, employment and student decisions have values above 0.7 . Thus all latent variables have good composite reliability. The results of the processed data are complete in Table 2.

Table 2 - Value of research variable reliability

\begin{tabular}{cc}
\hline Variable & Composite reliability \\
\hline Product & 0,850 \\
People & 0,734 \\
Prices & 0,805 \\
Promotion & 0,844 \\
Physical Evidence & 0,823 \\
Campus Image & 0,821 \\
Employment & 0,829 \\
Student decisions & 0,759 \\
\hline
\end{tabular}

Testing the hypothesis in this study can be seen from the magnitude of the critical value of the statistical t-test. The hypothesis is said to be significant at t-value> 1.96. Based on the results of hypothesis testing in Table 3, three variables were obtained which had a significant positive direct effect.

Table 3 - Hypothesis test results

\begin{tabular}{lll}
\hline Effects of Variable & T Statistics & Description \\
\hline Campus image $->$ Student decisions & 1,953 & Not significant \\
Employment $->$ Student decision & 0,286 & Not significant \\
People $->$ Student decision & 0,926 & Not significant \\
Physical evidence-> Student decision & 0,441 & Sot significant \\
Process-> Student decision & 2,113 & Significant \\
Product $->$ Student decision & 7,386 & Significant \\
Promotion $->$ Student decision & 3,384 & Significant \\
\hline
\end{tabular}

Based on data processing, it is known that the $R^{2}$ value of the student's decision to choose a study program at FKM Unand is 0.388 , meaning that the latent variable decision to choose students can be explained by latent product variables, people, process, physical evidence, campus image and employment at $38.8 \%$, the remainder is explained by other variables not examined in this study. These variables are price variables, place, interests, internal environment and external environment.

Product Effect on Choosing Decisions. The one hypothesis states that product has a significant effect on the decision to choose a study program. Based on Table 3, SEM results show the value of $t$ count at 7.386. The value of $t$ count is greater than the value of $t$ table so that the product has a positive and significant effect on the decision to choose a study program. The results of this study are reinforced by previous studies conducted by Rodic et al. (2016) which states that there is a positive and significant relationship between the product and the decision to choose a study program in the faculty of the University of Novi Sad. Other research shows the same results conducted by Hestiningtyas (2015), Merni (2011) which states that the products offered by universities have a positive and significant effect on the decision of students to choose study programs. Rahardjo et al (2015) concluded that there was a positive and significant influence between the products on student motivation in choosing the LP3I Banjarmasin Business College. This means that the knowledge and skills offered by universities are a consideration for students in deciding to choose a place to study.

Effects of People on Decisions to Choose. The second hypothesis states that people have a significant effect on the decision to choose a study program. Based on Table 3, SEM results show the value of $t$ count is 0.926 smaller than the value of $t$ table so that people have a negative effect and are not significant towards the decision to choose a study program. The results of this study are different from the results of the Ogunnaike study 
(2014) which found that the application of marketing mix elements, especially people, had a significant influence on the students' decision to choose study programs at Covenant University Nigeria. Osman (2013), Raharjo et al. (2015), Handayani (2017), also has different results, where people have a positive and significant influence on the decision of students to choose a study program in college. The results of this study indicate that students are not too influential in the presence of a lecturer or educational staff in the education process. Currently lectures can be done through e-learning, where this is one factor of the student's decision.

Effect of Process on Decision to Choose. The third hypothesis states that the process has a significant effect on the decision to choose a study program. Based on Table 3, SEM results show a value of $t$ count of 2.113. The value of $t$ count is greater than the value of $t$ table so that the product has a positive and significant effect on the decision to choose a study program. The results of this study are in line with the research conducted by Suryani et al. (2013), Kurniawati (2013) and Handayani (2017) which states that the process has a significant effect on the decision to choose students. Likewise the research conducted by Muhyidin (2014) states that the process has a significant effect on the decision of students to choose a place to study. The process in education services greatly determines the quality of a college graduate.

Effect of Promotion on Decision to Choose. The fourth hypothesis states that promotion has a significant effect on the decision to choose a study program. Based on Table 3, SEM results show the value of $t$ count of 3.384. The value of $t$ count is greater than the value of $t$ table so that the product has a positive and significant effect on the decision to choose a study program. The results of this study are reinforced by previous research conducted by Osman (2013) which states that promotion has a positive and significant influence on the decision of students to choose study programs at universities in Malaysia. Rudhumbu (2017) and Ivy (2008) state that promotion strategies carried out by universities have a significant effect on students' decisions about university choices. Rahardjo et al (2015) found that there was a positive and significant influence between promotions on the motivation of students in choosing the LP3I Banjarmasin Business College.

Effect of Physical Evidence on Decision to Choose. The fifth hypothesis states that physical evidence has a significant effect on the decision to choose a stud program. Based on Table 3, SEM results show a value of $t$ count of 0.441 smaller than the value of $t$ table so that physical evidence has a negative effect and is not significant for the decision to choose a study program. The results of this study are not in line with the research conducted by Suryani et al. (2013) shows that physical evidence has a significant influence on the decision to choose students in the Faculty of Economics, Islamic University of North Sumatra Al Munawaroh. Ogunnaike (2014), Merni (2011), Handayani (2017) also found different results, where physical evidence had a significant effect on students' decisions to study. The results of this study indicate that students are not too concerned about buildings, libraries, laboratories because this can be done in a shared lecture hall provided by the university. The center of the laboratory and university library is adjacent to the faculty.

Effect of Campus Image on Decision to Choose. The sixth hypothesis states that the campus image has a significant effect on the decision to choose a study program. Based on Table 3, SEM results show a $t$ value of 1.953 smaller than the value of t table so that the campus image has a positive and not significant effect on the decision to choose a study program. Several studies have different results from this study, namely research conducted by Saputro (2017) and Susilowati (2008) suggests that there is a significant effect of campus image on the decision of students to choose a place to study. The same research was also conducted by Risnawati (2012) who found that campus image had a significant effect on the decision to choose students at STIE Perbanas Surabaya. The brand image owned by IPB has an influence on the interest of students choosing IPB (Solikhah 2016). This is because FKM is part of a university that already has $A$ accreditation, brand image and big name in the eyes of the public, making respondents no longer pay attention to the campus image in the faculty. 
Influence of Employment on Decision to Choose. The seventh hypothesis states that employment has a significant effect on the decision to choose a study program. Based on Table 3, SEM results show the value of $t$ count of 0.286 smaller than the value of $t$ table so that employment has a positive and not significant effect on the decision to choose a study program. The results of this study are not in line with the research conducted by Yao-Chuan Tsai (2017) suggesting that future work has a significant influence on students choosing to study at Taiwan University. The same results were also found in Risnawati (2012) and Saputro (2007) employment opportunities that had a positive and significant effect on students' decisions in choosing a place to study.

Managerial Implications for Institutions:

1. The results of this study found that the product variable contributed the most to the students' decisions in choosing study programs at FKM Unand. For this reason, good and organized management must be carried out on study programs (IKM and Nutrition), so that the knowledge, skills and expertise possessed are able to compete and meet the needs of the labor market;

2. The health department is very popular with the community. To get information related to public health schools can get it through promotions carried out by the school. Variable promotion which influences students to choose study programs, through this, FKM Unand can promote excellence in the field of expertise possessed by IKM and Nutrition by involving various social media networks, with the aim of getting students who really have the basic knowledge and talent so that the quality of graduates will be better;

3. The educational process carried out by higher education determines the quality of graduates. The process of teaching and learning carried out by FKM Unand has been well seen from the graduates produced not much different when registering. Different and increasing results are needed for the quality of later graduates, such as creating a harmonious academic atmosphere between lecturers and students. Providing and explaining syllabus / method of lectures before the teaching and learning process begins to give direction to students. Alumni network strengthened and collaborated with hospitals and private companies in the health sector related to graduate placement.

\section{CONCLUSION AND SUGGESTIONS}

Students decide to choose a study program at FKM Unand because of the ease of getting a job, the field of specialization offered in accordance with their wants and needs and FKM has a good campus reputation. Product, process and promotion have the greatest influence on the decision to choose a study program at FKM Unand and show a positive and significant relationship with the decision to choose. People, physical evidence, campus image and employment have a positive, negative and not significant relationship to student decisions in choosing study programs at Unand FKM.

The need for an academic atmosphere to create an optimal teaching and learning process to achieve the mission of FKM Unand as a center for the development of public health human resources through the implementation of quality oriented education, competitiveness and character and professionalism. In making student decision making, it is also influenced by internal and external factors, while in this study it did not analyze the influence of these two factors, so for the next study to analyze the internal and external factors so that the influence of the decision to study program is known.

\section{REFERENCES}

1. Ayu Juli AD. 2014. Factors Affecting Student Decisions in Choosing Departments at the Faculty of Economics and Business (Feb) University of Education Ganesha (Undiksha) as a Lecture Place. Department of Management 2 (1): 1-8. 
2. Engel J, Blackwell FRD, Miniard PW. 1995. Consumer Behavior. 2nd volume. Translation from Consumer Behavior. Jakarta (ID): Bina Rupa Aksara.

3. [FKM] Faculty of Public Health Unand. 2016. Vision, Mission and work program of the Faculty of Public Health Unand in 2016. Padang (ID): Unand Faculty of Public Health.

4. Handayani A. 2017. Analysis of Marketing Mix against Student Decisions Choosing Study.

5. Programs at the Faculty of Economics, University of Bojonegoro [thesis]. Surakarta (ID):

6. Muhammadiyah University of Surakarta.

7. Haryanti. 2016. Analysis of factors that influence the high school students of Bogor city choose Bogor Agricultural Institute [thesis]. Bogor (ID): Bogor Agricultural Institute.

8. Hestiningtyas W. 2015. The effect of the marketing mix on the decisions of students choosing a special field of expertise in the education of the FKS UNS trade system. Proceedings of the National Seminar on Economic \& Business Education. ISBN: 978602-8580-19-9. http://snpe.fkip.uns.ac.id.

9. Ivy J. 2008. A new higher education marketing mix: the 7ps for MBA marketing. Journal of International Management 22 (4): 288-299.

10. Jogiyanto HM. 2011. Concepts and Applications of Structural Equation Modeling: Variant Based in Business Research. Yogyakarta (ID): UPP STIM YKPN.

11. [Kemenristekdikti] Ministry of Research, Technology and Higher Education. 2012. Minister of Technology Research and Higher Education Regulation (Permen) Number 12 of 2012 concerning higher education. Jakarta (ID): Kemenristekdikti.

12. Kurniawati D. 2013. The effect of marketing mix strategies on student decisions in choosing Widya Mandala Catholic University Madiun. Widya Warta Journal No. 01 Year XXXV II / January 2013: 65-80.

13. Merni IP. 2011. Analysis of the factors that influence student decision (Decision Making) choose the computer science department of the Faculty of MIPA Mulawarman University Using SPSS Software. Mulawarman Informatics Journal 6 (2): 86-94.

14. Muhyidin U. 2014. The effect of the marketing mix of educational services on students' decisions in choosing private universities in West Java. Proceedings of the multidisciplinary national seminar \& call for papers at UNISBANK. ISBN: 978-979-3649-81-8.

15. Ogunnaike O O. 2014. Empirical analysis of marketing mix strategy and student loyalty in education marketing. Mediterranean Journal of Social Sciences 5 (23): 2039-2117.

16. Osman M Zain. 2013. Factors influencing students' decisions in choosing private institutions of higher education in Malaysia: Asian Academy of Management Journal 18 (1): 75-90.

17. Purimahua. 2005. Factors that influence the behavior of students in choosing the Department of Development Economics at the Faculty of Economics, Maluku Christian University in Ambon. Journal of Consumer Behavior. Th. IX. No. 2. May: 541-551.

18. Rahardjo Sis, Firdaus, Reza M. 2015. Analysis of the effect of the marketing mix on socio-economic status and motivation on students' decisions in choosing courses (Study at the Education Institutions of Banjarmasin Business College). Journal of Management Insights 3 (1): 45-59.

19. Risnawati E. 2012. Factor analysis of student decision-making to choose an accounting department at STIE Perbanas Surabaya. Journal of The Indonesia Accounting Review 2 (1): 63-72. doi: 10.14414 / tiar.v2i01.318.

20. Rodic V, Nemanja. 2016. Application of marketing mix concept in student recruitment strategies: Evidence from University of Novi Sad. (SB). Scientific original paper 13 (3): 183-202.

21. Rudhumbu N. 2017. A choice of students of auniversity: a case af Botho University in Botswana. International Journal of Learning and Development 7 (2): 27-37.

22. Samat, Marnisah L. 2017. Marketing mix to the decision of students to choose private universities in the city of Palembang. Management journal and Sriwijaya Business 15 (4): 221-229.

23. Saputro M. 2017. Analisis faktor-faktor yang mempengaruhi keputusan mahasiswa dalam memilih program studi. Jurnal Pendidikan Informatika and Sains 6 (1): 83-94. 
24. Solikhah A. 2016. Pengaruh Kepribadian, motivasi, citra merek and lingkungan terhadap minat siswa SMA memilih Institut Pertanian Bogor. [tesis]. Bogor: Institut Pertanian Bogor.

25. Sugiyono. 2015. Statistik Nonparametris untuk Peneliti.Yogyakarta (ID): CV. Alfabeta.

26. Susilowati T. 2008. Factors Affecting Student Decision Making (Individual Internal Factor Factors, External Environment and Student Communication Strategy of Economic Education Study Program on Decision Making in Choosing the Special Field of Expertise in Office Administration of FKIP UNS). [thesis]. Semarang (ID): Sebelas Maret University

27. Suriyani W, Ginting P. 2013. Factors influencing the decision of students to choose the economics faculty of the Islamic University of North Sumatra, Al Munawaroh, Medan. Modernization Journal 9 (1): 33-48.

28. Widjaja D. 2106. Effects of Service Marketing Mix on Decisions in Choosing Higher Education (Study of UKRIDA \& UNTAR Students). Business Management Scientific Journal 16 (2): 119-216.

29. Yamamoto GT. 2006. University Evaluation-Selection: a Turkish Case. International Journal of Educational Management 20 (7): 559-569.

30. Yao-Chuan Tsai. 2017. Factors influencing international students to study at Universities in Taiwan. International Journal for Innovation Education and Research 5 (1): 4-11. 